Jurnal Teknologi Pendidikan, Vol. 14, No. 1, April 2021, e-ISSN: 2407-7437

\title{
IMPLEMENTASI E-LEARNING FLIPPED CLASSROOM SEBAGAI UPAYA PENINGKATAN KEMAMPUAN MAHASISWA DALAM MENDESAIN MATERI PENGEMBANGAN BAHAN AJAR NON CETAK
}

\author{
Evi Susilawati ${ }^{1}$ Imamul Khaira ${ }^{2}$ \\ ${ }^{1}$ Universitas Islam Sumatera Utara, ${ }^{2}$ Universitas Haji Sumatera Utara \\ ${ }^{1}$ evisusilawati@fkip.uisu.ac.id,,'imamulkhaira@gmail.com
}

\begin{abstract}
Abstrak: Penelitian ini bertujuan untuk meningkatkan kemampuan mahasiswa dalam mendesain materi pengembangan bahan ajar non cetak melalui e-learning flipped classroom. Penelitian ini berjenis penelitian tindakan kelas (PTK) dengan mengikuti langkah-langkah penelitian yaitu: perencanaan, pelaksanaan, observasi, analisis dan refleksi. Subjek penelitian ini adalah mahasiswa semester V Program Studi Dosenan Pancasila dan Kewarganegaraan Fakultas Keguruan dan Ilmu Dosenan Universitas Islam Sumatera Utara pada tahun pelajaran 2020/2021. Pelaksanaan penelitian tindakan kelas ini dilakukan pada matakuliah Pengembangan Bahan Ajar dengan jumlah mahasiswa 17 orang. Teknik pengumpulan data pada penelitian ini menggunakan data kuantitatif. Alat pengumpulan data kuantitatif ini menggunakan instrumen materi pengembangan bahan ajar non cetak dengan menggunakan pilihan berganda yang diberikan secara online, sementara pada data kualitatif menggunakan hasil observasi kemampuan mahasiswa dalam mendesain materi pengembangan bahan ajar non cetak di kelas e-learning. Hasil penelitian ini menunjukkan terdapat peningkatan kemampuan mahasiswa dalam mendesain materi pengembangan bahan ajar non cetak dengan menggunakan e-learning flipped classroom.
\end{abstract}

Kata Kunci: Kemampuan Mahasiswa, Bahan Ajar Non Cetak, E-Learning Classroom

\begin{abstract}
This study aims to improve students' abilities in designing non-print teaching materials through elearning flipped classrooms. This research is a classroom action research (CAR) by following the research steps, namely: planning, implementing, observing, analyzing and reflecting. The subjects of this study were students in the fifth semester of the Pancasila and Citizenship Lecturer Study Program, the Teaching and Lecturer Faculty of the Islamic University of North Sumatra in the 2020/2021 school year. The implementation of this classroom action research was carried out in the course of Teaching Material Development with a total of 17 students. Data collection techniques in this study using quantitative data. This quantitative data collection tool uses non-printed teaching material development materials instruments using multiple choices provided online, while the qualitative data uses observations of students' abilities in designing non-print teaching material development materials in e-learning classes. The results of this study indicate that there is an increase in the ability of students in designing non-print teaching materials development materials using e-learning flipped classrooms.
\end{abstract}

Keywords: Student Activity, Non-Printed Teaching Materials, E-Learning Flipped Classroom

\section{PENDAHULUAN}

Sejak mewabahnya Pandemi Covid19 telah memberikan gambaran kepada kita tentang kegiatan pembelajaran di masa depan dengan berbantuan teknologi. Perubahan kegiatan pembelajaran yang telah berubah drastis ini ditopang dengan berkembangnya teknologi informasi di era revolusi industri 4.0. Fenomena pembelajaran dengan aktifitas digitalisasi terkoneksi secara virtual (Schwab, 2017). Di era digital ini, proses pembelajaran dilakukan tanpa batas ( Susilawati dan Khaira, 2020). Interaksi antara dosen dan mahasiswa dilakukan melalui kegiatan digital tanpa mengunjungi kelas fisik.

Meskipun pembelajaran dengan aktifitas digitalisasi ini telah dilaksanakan sejak tahun 2020 yang lalu, tetapi tetap saja tidak dapat menggantikan peran dosen dalam menciptakan dan interaksi belajar antara dosen dan mahasiswa yang humanis. Kondisi ini sangat beralasan sebab dalam melakukan kegiatan pembelajaran bukan hanya sekadar memperoleh pengetahuan tetapi juga berkaitan dengan transformasi nilai-nilai, kerja sama, dan keaktifan mahasiswa (Susilawati, 2020).

Proses pembelajaran yang baik tentunya dapat meningkatkan keterampilan sosial dan kesadaran 
kelas sosial antara dosen dan mahasiswa (Susilawati, 2020). Dalam kegiatan pembelajaran tersebut setiap dosen harus dapat menjamin bahwa pembelajaran digitalisasi yang dilakukan bukan hanya pada kegiatan mentransmisi pengetahuan, tapi juga bagaimana memastikan materi pembelajaran tetap tersampaikan dengan baik.. Tentunya ini juga menjadi kesempatan bagi semua dosen untuk dapat membantu dan membawa mahasiswa menjadi kompeten untuk abad ke-21 (Hendayana, 2021).

Pembelajaran digitalisasi ini dapat melatih dan menanamkan kebiasaan mahasiswa dengan belajar secara mandiri melalui berbagai kelas digital. Selain itu mahasiswa dapat juga aktif dalam menyelesaikan permasalahan di kelas digital serta menghadapi permasalahan yang mereka temukan dikehidupan nyata (Susilawati, 2020). Kondisi ini bukan hanya menjadi tantangan bagi mahasiswa, namun juga para dosen dalam menyampaikan materi pembelajaran.

Kegiatan pembelajaran digitalisasi mengharuskan para dosen untuk memastikan mahasiswa memahami materi pembelajaran yang mereka sampaikan. Kenyataan yang ditemui dalam kegiatan pembelajaran digitalisasi dengan menggunakan e-learning matakuliah Pengembangan Bahan Ajar di program studi Dosenan Pancasila dan Kewarganegaraan Fakultas Keguruan dan Ilmu Dosen Universitas Islam Sumatera Utara tidak mampu mengaktifkan mahasiswa dalam menyelesaikan permasalahan di kelas elearning. Berdasarkan hasil observasi yang peniliti lakukan dalam pembelajaran e-learning ini ditemukan masalah-masalah sebagai berikut: (1) mahasiswa cenderung pasif karena menunggu informasi yang disampaikan oleh mahasiswa; (2) dosen dalam menyampaikan materi pembelajaran tidak dapat memastikan bahwa mahasiswa telah memahami materi pembelajaran yang mereka sampaikan; (3) kurangnya interaksi yang intens antara dosen dan mahasiswa; (3) perhatian mahasiswa hanya tertuju pada materi pembelajaran pada kelas elearning saja, (4) pembelajaran e-learning tidak dapat menarik motivasi mahasiswa untuk belajar menemukan dan memecahkan masalah yang terdapat dilingkungan sosial mereka.

Mencermati permasalahan-permasalahan yang peneliti temukan dalam pembelajaran digitalisasai dengan menggunakan e-learning pada matakuliah Pengembangan Bahan Ajar ini, perlu kiranya dilakukan perbaikan pembelajaran e-learning secara inovatif. Untuk menyiasati permasalahan -permasalahan pembelajaran $e$ larning di atas, peneliti melakukan perubahan strategi pembelajaran e-learning dengan menerapkan metode e-learning flipped classroom.

\section{A. Strategi E-Learning Flipped Classroom}

Penggunaan e-learning dalam kegiatan pembelajaran memberikan fasilitas yang bervariasi bagi pembelajaran digital. Berdasarkan penelitian Bariah, Rahdian, dan Tresna (2019) mengemukakan bahwa penggunaan e-learning memerlukan strategi pembelajaran yang berbeda dari pembelajaran tradisional. Strategi pembelajaran dalam $e$ learning memerlukan tidak lagi dilakukan secara satu arah saja tetapi harus mampu membangun komunikasi antara dosen dan mahasiswa, membangun kerjsama dalam kelompok, pemecahan masalah yang dihadapi mahasiswa dalam kehidupan sehari-hari, membangun kreativitas dan pemikiran kritis mahasiswa yang kesemuanya itu dapat membangun kompetensi dasar di abad kedua puluh satu (Chan dkk, 2017). Salah satu strategi pembelajaran yang mampu mengakomodir kemampuan abad kedua puluh satu dalam kegiatan pembelajaran e-learning adalah dengan menggunakan e-learning flipped classroom.

Sebagai sebuah strategi pembelajaran, $e$ learning flipped classroom merupakan setrategi pembelajaran aktif yang inovatif yang berpusat kepada mahasiswa (student centered learning). Kim, Kim, Khera \& Getman (2014) menjelaskan bahwa strategi pembelajaran, e-learning flipped classroom terdiri atas prinsip-prinsip sebagai berikut: (1) memberikan kesempatan kepada mahasiswa untuk memperoleh informasi awal sebelum kegiatan kelas; (2) mendorong mahasiswa untuk menonton ceramah online dan bersiap sebelum kegiatan kelas; (3) mengorganisir metode penilaian; (4) menghubungkan kegiatan di kelas dengan kegiatan di luar kelas; (5) memberikan panduan yang dinyatakan dengan jelas dan terorganisir dengan baik; (6) menyediakan waktu yang cukup untuk menyelesaikan tugas; (7) mendorong mahasiswa untuk membangun komunitas belajar; (8) memberikan umpan balik langsung tentang pekerjaan individu atau kelompok; (9) menyediakan penggunaan teknologi yang familiar yang dapat diakses dengan mudah oleh 
mahasiswa.

Strategi pembelajaran, e-learning flipped classroom memberikan banyak peluang kepada mahasiswa untuk belajar aktif dan inovatif. Berdasarkan temuan Enfield (2013) menunjukkan bahwa penggunaan strategi pembelajaran, e-learning flipped classroom mahasiswa didorong untuk keluar kelas untuk belajar kapan saja dan di mana saja. Hasil penelitian lainnya menunjukkan bahwa $e$ learning flipped classroom mampu menumbuhkan kecepatan belajar mereka sendiri tanpa melalui instruksi lanbgsung dari dosen dan mereka mampu berpartisipasi penuh dalam belajar sehingga kinerja mahasiswa menunjukkan perubahan yang positif (Hung, 2015). Pendapat senada dikemukakan oleh McLaughlin dan Rhoney (2015) mengungkapkan bahwa penggunaan strategi pembelajaran, e-learning flipped classroom mampu meningkatkan aktifitas dosen dalam memampukan mahasiswa untuk mendesain berbagai jenis bahan ajar yang dapat digunakan mahasiswa dalam kegiatan pembelajaran di kelas kelak ketika mereka menjadi guru.

B. Kemampuan Mahasiswa Dalam Mendesain Bahan Ajar Non Cetak Pada Mata Kuliah Pengembangan Bahan Ajar

Untuk mendefinisikan pengertian bahan ajar non cetak, terlebih dahulu kita harus memahami arti dari bahan ajar tersebut. Bahan ajar adalah segala macam bahan yang digunakan untuk membantu dosen dalam melaksanakan kegiatan pembelajarn di kelas (Abadi, Pujiastuti, \& Assaat, 2020). Bahan ajar juga diartikan sebagai bentuk-bentuk bahan yang digunakan untuk membantu dosen dalam melaksanakan kegiatan pembelajaran (Mudlofar, 2017).

Merujuk pada pengertian-pengertian mengnai bahan ajar di atas, dapat di berikan kesimpulan bahwa bahan ajar dikaitkan dengan segala sesuatu yang berhubungan dengan penbelajaran yang mampu memberikan akselerasi bagi mahasiswa dalam memahami materi yang diajarkan dosen. Sitohang (2014) membagi bahan ajar atas dua jenis yaitu bahan ajar cetak yaitu modul, handout, dan lembar kerja dan non cetak non cetak yaitu realita, bahan ajar yang dikembangkan dari barang sederhana, bahan ajar diam display, video, audio, dan Overhead Transparanceis (OHP). Penelitian ini mengkaji jenis bahan ajar non cetak yaitu video.
Pentingnya pengembangan bahan ajar non cetak seperti video ini karena mampu menjadikan sumber belajar yang kuat dalam aktivitas pembelajaran digital. Yoosef \& Chatti (2014) mengemukakan bahwa pentingnya mengembankan video dalam bahan ajar disebabkan karena video mempunyai berbagai keunggulan sebagai berikut: (1) video memiliki fitur unik yang menjadikannya pembelajaran yang efektif yang dipadukan dengan strategi pembelajaran e-learning yang dapat meningkatkan pembelajaran berbasis kelas digital; (2) video dapat membantu mahasiswa dengan memvisualisasikan bagaimana belajar mandiri dengan kegiatan pembelajaran flipped classroom di mana materi dapat diberikan pada saat belajar lalu peserta didik dapat mempelajari video yang dibagikan pada saat proses pembelajaran, lalu mereka dapat mengulas video pembelajaran, menjawab materi yang terdapat di dalam video tersebut; (3) video dapat menunjukkan informasi dan detail yang sulit dalam menjelaskan dengan teks atau foto statis; (4) video juga bisa menarik perhatian peserta didik, sehingga memotivasi mereka terlibat aktif serta berkolabolari memahami materi yang diberikan kepada mereka; (5) pengembangan video sebagai bahan ajar dapat menghasilkan hasil belajar yang lebih baik; (6) video mampu mendukung gaya belajar peserta didik yang berbeda, kerana dalam belajar peserta didik ada yang mempunyai gaya belajar visual dan audio visual.

Melihat begitu banyak keunggulan pengembangan bahan ajar video dalam kegiatan pembelajaran maka penting kiranya membimbing mahasiswa agar mampu mendesain pengembangan bahan ajar video ini sebagai bahan ajar non cetak pada mata kuliah pengembangan bahan ajar ini. Adapun desain pengembangan bahan ajar video ini merupakan video interaktif. Video interaktif merupakan video yang berisi tuntunan praktis yang disajikan lewat presentasi audio visual seperti gambar dan suara dan yang dilengkapi dengan suara penuntun yang jelas dan mudah dipahami dan oleh peserta didik. Video interaktif ini dibuat dalam dalam sebuah program autorun, dengan panduan compact disk interaktif yang mana peserta didik dapat belajar secara mandiri setiap saat sehingga peserta didik dapat mendalami materi dengan baik.

Keutamaan video interaktif menurut Yoosef \& Chatti (2014) diuraikan sebagai berikut: (1) 
lebih praktis dalam pelaksanaan pembelajaran yang menyenangkan dan tidak membosankan; (2) para peserta didik dapat mengukur tenaga yang harus ia keluarkan untuk mendapatkan nilai yang baik, dapat dipantau oleh pendidik; dan (3) menumbuhkan pemahaman tentang materi secara menyenangkan.

Kemampuan mahasiswa dalam megembangkan bahan ajar non cetak dalam bentuk video pada mata kuliah Pengembangan Bahan Ajar di program studi Pancasila dan Kewarganegaraan Fakultas Keguruan dan Ilmu Dosen Universitas Islam Sumatera Utara ini dilakukan berdasarkan pada indikator-indikator berikut: (1) Kemampuan mengoperasikan program dengan indikator : (a) Kemampuan mahasiswa dalam megembangkan bahan ajar non cetak dalam bentuk video pada mata kuliah Pengembangan Bahan Ajar di program studi Pancasila dan Kewarganegaraan Fakultas Keguruan dan Ilmu Dosen Universitas Islam Sumatera Utara ini dilakukan berdasarkan pada indikator-indikator berikut: (1) kemampuan dalam mendesain operasi program video dengan indikator: (a) mendesain keluwesan dan kebebasan memilih menu materi, (b) mendesain kemudahan perpindahan sub materi, (c) mendesain konsistensi navigasi, (d) mendesain menu bantuan; (2) kemampuan dalam mendesain tampilan program video dengan indikator: (a) mendesain tata letak (lay out), (b) mendesain keterbacaan teks, (c) mendesain keterbacaan teks, (d) mendesain kualitas gambar, (e) mendesain kualitas animasi, (f) mendesain kualitas video, (g) mendesain komposis warna, (h) mendesain daya dukung musik, dan (i) mendesain pemilihan back ground.

\section{METODE PENELITIAN}

Penelitian yang berjudul "Implementasi ELearning Flipped Classroom Sebagai Upaya Peningkatan Kemampuan Mahasiswa Dalam Mendesain Materi Pengembangan Bahan Ajar Non Cetak " ini berjenis penelitian tindakan kelas (action research). Tujuan utama dari penelitian tindakan kelas ini adalah adanya perbaikan kemampuan mahasiswa dalam mendesain materi pengembangan bahan ajar non cetak dan keterlibatan mahasiswa dalam mendesain materi pengembangan bahan ajar non cetak.

Model penelitian tindakan kelas ini mengikuti model Mc, Kernan (1982) seperti yang dikutip Djajadi (2019) yang terdiri dari dua siklus dengan masing-masing siklus terdiri atas tujuh tahapan. Setiap tindakan terdiri atas tahapan-tahapan sebagai berikut: (1) Tahap identifikasi masalah yaitu tahapan yang melihat dan menemukan masalah-masalah yang terjadi dalam pembelajaran mata kuliah pengembangan bahan ajar. Pada tahap ini dilakukan identifikasi masalah pembelajaran dan menjadi pondasi awal kegiatan penelitian kedepannya; (2) Tahap penyelidikan. Pada tahapan ini dilakukan penyelidikan kenapa muncul permasalahan dalam kegiatan pembelajaran mata kuliah pengembangan bahan ajar. Berdasarkan hasil penyelidikan terhadap permasalahn pembelajaran mata kuliah pengembangan bahan ajar dapat dilakukan pemfokusan masalah yang kemudian dirumuskan menjadi masalah penelitian. Berdasarkan rumusan masalah tersebut maka dapat ditetapkan tujuan penelitian yaitu untuk meningkatkan kemampuan mahasiswa dalam mendesain materi pengembangan bahan ajar non cetak melalui $e$ learning flipped classroom; (3) Tahapan rencana umum yang merupakan seperangkat rencana awal dalam melakukan penewlitian ini; (4)Tahap implementasi langkah tindakan 1, yang mana pada tahap ini, kegiatan penelitian ini peneliti akan menerapkan atau melakukan perlakuan pada kelas sampel dengan tujuan meningkatkan kemampuan mahasiswa dalam mendesain materi pengembangan bahan ajar non cetak melalui $e$ learning flipped classroom; (5) Tahap memonitor implementasi yang aman pada tahap ini dilakukan untuk melihat hasil implementasi strategi pembelajaran e-learning flipped classroom pada kelas sampel. Kegiatan pada penelitian ini adalah untuk mendata dan mencatat hasil-hasil dari implementasi strategi pembelajaran e-learning flipped classroom pada tahap selanjutnya; (6) Tahap penyelidikan yang mana pada tahapan ini, kegiatan penelitian untuk menjelaskan tentang kegagalan-kegagalan dari implementasi strategi pembelajaran e-learning flipped classroom dan faktor-faktor apa aja yang bisa menyebabkan terjadinya kegagalan tersebut; (7) Tahap merevisi ide umum yang mana pada tahapan ini dilakukan tahapan penelitian lagi yang didasarkan data-data yang sudah didapat pada tahap-tahap sebelumnya. Tentunya tahapan penelitian ini dilakukan jika implementasi telah mengalami kegagalan dan tidak memenuhi harapan serta tujuan penelitian dari penelitian ini.

Subjek dalam penelitian ini adalah mahamahasiswa semester V Program Studi Pendidikan Pancasila dan Kewarganegaraan Fakultas Keguruan dan Ilmu Pendidikan (FKIP) Universitas Islam Suamtera Utara. Pelaksanaan penelitian tindakan kelas ini dilakukan pada 
matakuliah Pengembangan Bahan dengan jumlah 17 orang. Peran dan posisi peneliti dalam penelitian ini sebagai dosen yang bertindak langsung melakukan kegiatan peembelajaran matakuliah Pengembangan Bahan Ajar yang dibantu oleh dua orang observer. Kegiatan penelitian ini dilakukan pada semester ganjil tahun pelajaran 2020/2021.

Penggunaan teknik pengumpulan data pada penelitian ini terdiri dari data kuantitatif dan kualitatif yang mana data kuantitaif diperoleh melalui instrumen tes hasil belajar kemampuan mendesain materi pengembangan bahan ajar non cetak dalam bentuk pilihan berganda, sementara data kualitatif diperoleh berdasarkan hasil observasi melalui lembar aktifitas mahasiswa dalam mendesain materi pengembangan abhan ajar non cetak dengan mengguanan strategi pembelajaran e-learning flipped classroom. Indikator keberhasilan pada penggunaan strategi pembelajaran e-learning flipped classroom terhadap kemampuan mahasiswa dalam mendesain materi bahan ajar non cetak berada pada rentang skor $75 \%-100 \%$. Selanjutnya untuk tes hasil belajar mahasiswa terhadap kemampuan mereka dalam mendesain materi bahan ajar non cetak berada pada rentang skor $70 \%-100 \%$.

\section{HASIL DAN PEMBAHASAN}

Kemampuan Mahasiswa dalam Mendesain Materi Pengembangan Bahan Ajar Non Cetak Dengan Mengimplementasikan Strategi Pembelajaran E-Learning Flipped Classroom
Pada Mata Kuliah Pengembangan Bahan Ajar

Kemampuan mahasiswa dalam mendesain materi pengembangan bahan ajar non cetak dengan menggimplementasikan strategi pembelajaran $e$ learning flipped classroom dengan menggunakan lembar pengamatan diperoleh data pada siklus pertama dengan ratarata perolehan skor 65,38 dan pada siklus kedua menujukkan rata-rata perolehan skor 79,69. Merujuk pada perolehan skor tersebut, terjadi peningkatan kemampuan mahasiswa dalam mendesain materi pengembangan bahan ajar non cetak dengan menggimplementasikan strategi pembelajaran e learning flipped classroom. Mencermati pada perolehan skor rata-rata pada Tabel 2, dapat dilihat terjadi peningkatan kemampuan mahasiswa dalam mendesain materi pengembangan bahan ajar non cetak dengan menggimplementasikan strategi pembelajaran $e$ learning flipped classroom.dari siklus I ke siklus II sebesar $14.31 \%$ Perolehan nilai kemampuan mahasiswa dalam mendesain materi pengembangan bahan ajar non cetak dengan mengimplementasikan strategi pembelajaran $e$ learning flipped classroom pada siklus kedua ini telah mencapai indikator keberhasilan dalam penelitian ini yang berada pada rentang skor $75 \%$ $100 \%$ sehingga penelitain ini berhenti pada siklus kedua. Perolehan score kemampuan mahasiswa dalam mendesain materi pengembangan bahan ajar non cetak dengan mengimplementasikan strategi pembelajaran e-learning flipped classroom pada mata kuliah Pengembangan Bahan Ajar dapat dilihat pada Tabel 1. berikut ini:

Tabel 1. Kemampuan Mahasiswa Dalam Mendesain Materi Pengembangan Bahan Ajar Non Cetak Dengan Mengimplementasikan Strategi Pembelajaran E- Learning Flipped Classroom

\begin{tabular}{llccc}
\hline $\begin{array}{c}\text { Lembar } \\
\text { Observasi }\end{array}$ & \multicolumn{1}{c}{$\begin{array}{c}\text { Kemampuan Mahasiswa dalam Mendesain Materi } \\
\text { Pengembangan Bahan Ajar Non Cetak Dengan } \\
\text { Mengimplementasikan Strategi Pembelajaran } \\
\text { Flipped Classroom }\end{array}$} & $\begin{array}{c}\text { E-Learning } \\
\text { Siklus } \\
\mathbf{1}\end{array}$ & $\begin{array}{c}\text { Siklus } \\
\mathbf{2}\end{array}$ \\
\hline Indikator 1 & Mendesain keluwesan dan kebebasan memilih menu materi & 68 & 77 \\
\hline Indikator 2 & Mendesain kemudahan perpindahan sub materi, & 62 & 80 \\
\hline Indikator 3 & Mendesain konsistensi navigasi, & 66 & 84 \\
\hline Indikator 4 & Mendesain menu bantuan; & 60 & 79 \\
\hline Indikator 5 & Mendesain tata letak (lay out), & 67 & 81 \\
\hline Indikator 6 & Mendesain keterbacaan teks, & 61 & 77 \\
\hline Indikator 7 & Mendesain keterbacaan teks, & 65 & 83 \\
\hline Indikator 8 & Mendesain kualitas gambar, & 63 & 79 \\
\hline Indikator 9 & Mendesain kualitas animasi, & 71 & 77 \\
\hline Indikator 10 & Mendesain kualitas video & 70 & 78 \\
\hline Indikator 11 & Mendesain komposis warna, & 68 & 80 \\
\hline Indikator 12 & Mendesain daya dukung musik, dan & 65 & 80 \\
\hline
\end{tabular}


Indikator 13 Mendesain pemilihan back ground. 64 81

Rata-Rata Kemampuan Mahamahasiswa dari Siklus 1 ke Siklus 2 Persentase Kenaikan Kemampuan Mahasiswa dari Siklus 1 ke Siklus 2

$65,38 \quad 79,69$ $14,31 \%$

\section{Peningkatan Hasil Belajar Pada Materi Pengembangan Bahan Ajar Non Cetak Dengan Mengimplementasikan Strategi Pembelajaran E-Learning Flipped Classroom}

Kemampuan mahasiswa dalam menjawab materi pengembangan bahan ajar non cetak dengan mengimplementasikan strategi pembelajaran e-learning flipped classroom pada mata kuliah Pengembangan Bahan Ajar dengan menggunakan tes hasil belajar diperoleh data yang dapat dilihat pada Tabel 2 berikut ini:

Tabel 2. Peningkatan Hasil Belajar Mahasiswa Dalam Menjawab Materi Pengembangan Bahan Ajar Non Cetak Dengan Mengimplementasikan Strategi Pembelajaran E-Learning Flipped Classroom Pada mata kuliah Pengembangan Bahan Ajar

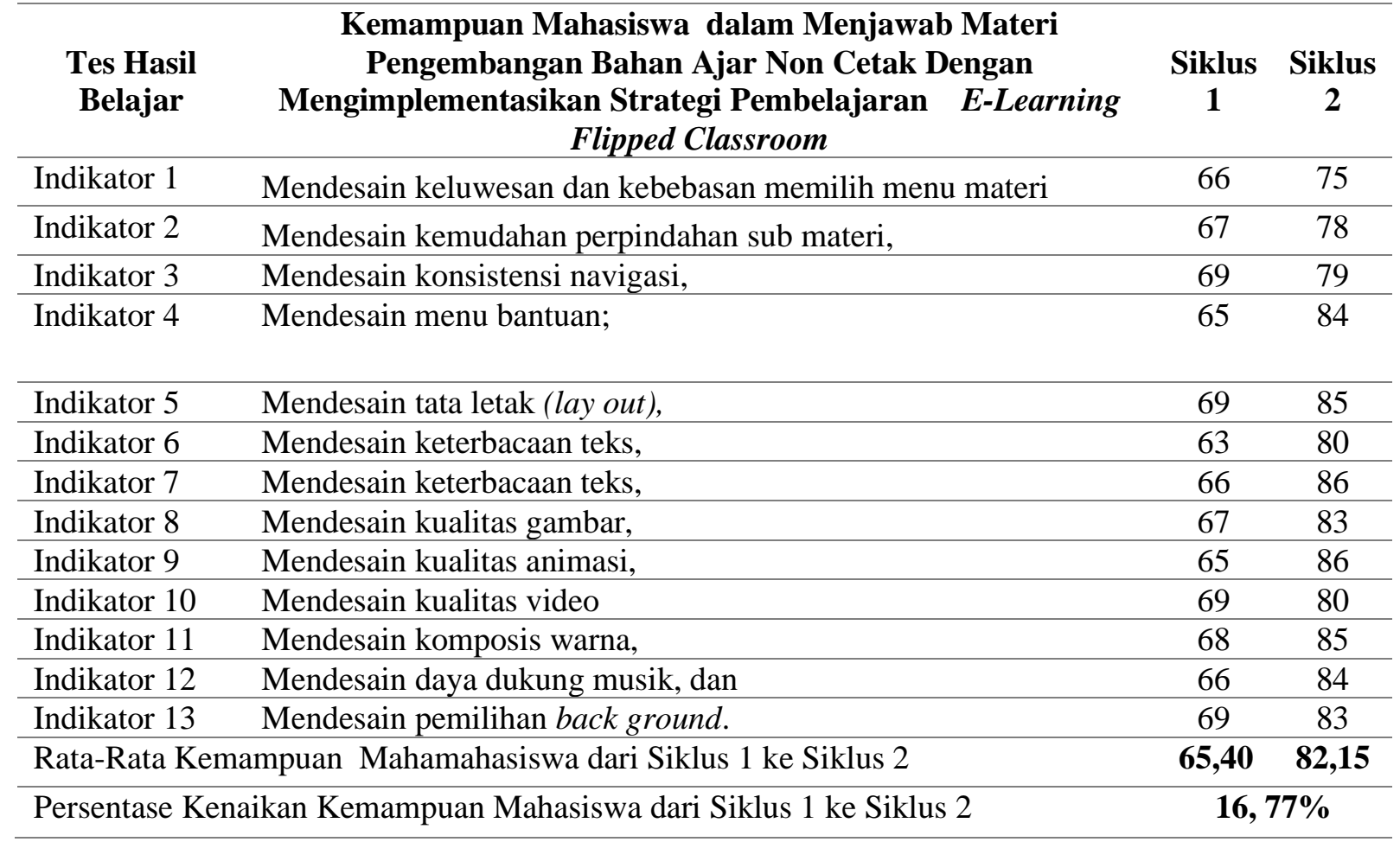

Melihat pada perolehan skor pada Tabel 2, dapat dilihat telah terjadi peningkatan hasil belajar mahasiswa dalam menjawab materi pengembangan bahan ajar non cetak diperoleh data pada siklus pertama dengan rata-rata perolehan skor 65,40 dan pada siklus kedua menujukkan rata-rata perolehan skor 82,15. Merujuk pada perolehan skor tersebut, dapat dinyatakan telah terjadi hasil belajar mahasiswa pada materi pengembangan bahan ajar non cetak dengan menggimplementasikan strategi pembelajaran e learning flipped classroom. Mencermati pada perolehan skor rata-rata pada Tabel 2, dapat dilihat telah terjadi peningkatan hasil belajar mahasiswa dalam menjawab materi pengembangan bahan ajar non cetak pada mata kuliah Pengembangan Bahan Ajar dengan menggimplementasikan strategi pembelajaran $e$ learning flipped classroom.dari siklus I ke siklus II sebesar $16.77 \%$. Perolehan hasil belajar mahasiswa pada materi pengembangan bahan ajar non cetak pada siklus kedua ini telah mencapai indikator keberhasilan dalam penelitian ini yang berada pada rentang skor $70 \%-100 \%$ sehingga penelitain ini berhenti pada siklus kedua.

Merujuk pada hasil temuan-temuan penelitian di atas dapat dipahami bahwa penggunaan strategi pembelajaran $e$ learning 
flipped classroom telah mampu meningkatkan kemampuan mahasiswa dalam mendesain materi pengembangan bahan ajar non cetak pada mata kuliah Pengembanagn bahan Ajar di program studi Pendidikan Pancasila dan Kewarganegaraan Fakultas Kependidikan Universitas Islam Sumatera Utara. Temuan ini sangat berasalasan karena strategi pembelajaran e learning flipped classroom karena stratrgi pembelajaran cocok pada pembelajaran digital yang sedang gencargencarnya digunakan pada saat di masa Pandemi Covid-19 saat ini. Temuan penelitian ini mendukung temuan peneilitian yang dikemukakan oleh Thongkoo \& Daungcharone (2019) yang menyatakan bahwa strategi pembelajaran e-learning flipped classroom merupakan strategi pembelajaran yang berpusat kepada mahasiswa dan efektif disunakan pada pembelajaran berbasis digital.

Temuan penelitian menunjukkan bahwa strategi pembelajaran e-learning flipped classroom menggunakan pendekatan pembelajaran yang mempromosikan keterlibatan aktif mahasiswa dan mampu membangkitkan mahasiswa dalam mendesain pembelajaran dengan menggunakan video karena di dalam strategi pembelajaran e-learning flipped classroom mengajak mahasiswa untuk belajar terbalik yang mana mahasiswa diberikan tutorial mengenai pembuatan video, selanjutnya mahasiswa di ajak mengamati dan merefleksi dan juga praktik dalam membuat video sehingga mahasiswa dapat belajar secara mandiri. Temuan penelitian ini mendukung hasil penelitian yang dilakukan oleh Bond (2020) yang mengemukakan bahawa selama mahasiswa belajar menggunakan strategi pembelajaran $e$ learning flipped classroom akan membentuk pengalaman pengalaman belajar aktif mahasiswa sehingga mahasiswa memiliki kesempatan untuk melakukan, mempraktikkan merenungkan, menyelidiki terlibat langsung kegiatan pembelajaran.

Penggunaan strategi pembelajaran e learning flipped classroom telah mampu meningkatkan hasil belajar mahasiswa dalam menyelesaikan materi pengembangan bahan ajar non cetak pada mata kuliah Pengembanagn bahan Ajar di program studi Pendidikan Pancasila dan Kewarganegaraan Fakultas Kependidikan Universitas Islam Sumatera Utara. Hal ini membuktikan strategi pembelajaran e learning flipped classroom mampu membangun kinerja kognitif mahasiswa yang lebih tinggi. Melalui ruang kelas digital setiap mahasiswa dapat membangun pengalaman interaktif dan inovatif berbasis video dan selama kegiatan pembelajaran mahasiswa dilatih untuk tidak hanya mengingat dan memahami konten pembelajaran saja tetapi juga mampu menerapkan, menganalisis, mengevaluasi, dan membuatnya. Strategi pembelajaran $e$ learning flipped classroom mampu memperkaya pengalaman belajar mahasiswa dengan melibatkan mahasiswa dalam memahami masalah, menyediakan solusi, dan merancang dan membuat sebuah model atau desain. Pengalaman belajar seperti ini mampu memperkaya dan mempromosikan keterampilan tingkat tinggi karena mahasiswa ditantang dengan berpikir lebih kritis dan secara mendalam sehingga mereka mampu membuat hubungan antara pengetahuan lama dan baru. Temuan penelitian ini medukung hasil penelitian yang dilakukan Turan \& Akdag Cimen (2020) yang mengemukaakan bahwa terdapat efek positif implementasi strategi pembelajaran e learning flipped classroom terhadap keterampilan akademik dan pribadi mahasiswa. Hasil penelitian ini juga mendukung temuan penelitian yang dilakukan Shi dkk (2020) yang menyatakan bahwa implementasi strategi pembelajaran $e$ learning flipped classroom dalam pembelajaran memungkinkan mahasiswa mencapai dimensi kognitif, keterampilan berpikir tingkat tinggi, kinerja akademik, domain efektif, dan membantu mahasiswa untuk meningkatkan prestasi belajar mereka.

\section{PENUTUP}

Berdasarkan temuan penelitian mengenai implementasi e-learning flipped clasroom sebagai upaya peningkatan kemampuan mahasiswa dalam mendesain pengembangan bahan ajar non cetak dapat disimpulkan sebagai berikut:

1. Terdapat peningkatan kemampuan mahasiswa dalam mendesain materi pengembangan bahan ajar non cetak dengan menggimplementasikan strategi pembelajaran e learning flipped classroom.

2. Terdapat peningkatan hasil belajar mahasiswa dalam menjawab materi pengembangan bahan ajar non cetak padamata kuliah Pengembangan Bahan Ajar dengan menggimplementasikan strategi pembelajaran e learning flipped classroom.

Berdasarkan pada kesimpulan pada penelitian penelitian yang telah dilaksanan, beberapa 
saran yang dapat diberikan peneliti sebagai berikut:

1. Dosen hendaknya menggunakan strategi pembelajaran yang mampu memungkinkan mahasiswa untuk mencapai dimensi kognitif keterampilan berpikir tingkat tinggi, kinerja akademik, domain efektif, dan membantu mahasiswa untuk meningkatkan prestasi belajar mahasiswa sehingga disarankan agar dosen senantiasa adaptif dan aktif dalam menggunakan berbagai bahan ajar digital.

2. Untuk peneliti yang lain yang ingin melakukan penelitian lanjut tentang implementasi $e$ learning flipped clasroom sebagai upaya peningkatan kemampuan mahasiswa dalam mendesain pengembangan bahan ajar non cetak disarankan agar lebih memperhatikan karakteristik mahasiswa agar strategi pembelajaran ini dapat dilaksanakan lebih efektif.

\section{DAFTAR PUSTAKA}

Abadi, M.K, Pujiastuti, H. \& Assaat. L.D. ( 2020). Development of Teaching Materials Based Interactive Scientific Approach towards the Concept of Social Arithmetic For Junior High School Student. Series: Journal of Physics.

Bariah, Siti Husnul. Rahadian, Dian. Tresna. M, Iwan Putra. (2019). Implementasi Elearning Dengan Model Flipped Classroom Dalam Aktivitas Belajar Mahasiswa Pada Mata Pelajaran Sistem Komputer. Jurnal PETIK. Volume 5, Nomor 2, September 2019. Diakses pada Tanggal 17 Januari 2021.

Dari https://journal.institutdosenan.ac.id/index. php/petik/article.

Bond, M. (2020). Facilitating Student Engagement Through The Fipped Learning Approach in K-12: A sysTematic Review. Computers \& Education. Diakses Tanggal 19 Januari 2021 Dari: https://doi.org/10.1016/j.compedu.2020.10 $\underline{3819}$.

Chan, Cecilia. K. Y. (2017). A Review of Literature on Challenges in the Development and Implementation of Generic Competencies In Higher Education Curriculum. International Journal of Educational Development. 57(1).

Djajadi, Muhammad. (2019). Pengantar Penelitian Tindakan Kelas (Classroom
Action Research). Yogyakarta: Arti Bumi Intaran.

Enfield, J. (2013). Looking at The Impact of The Flipped Classroom Model of Instruction on Undergraduate Multimedia Students at CSUN. Tech Trends, 57 (6), 2013. Diakses padaTanggal 12 Januari Dari https://link.springer.com/article.

Hendayana, Yayat. (2020). Tantangan Dunia Dosenan Di Masa Pandemi. Diakses pada Tanggal 15 Maret 2021, Dari https://dikti.kemdikbud.go.id/kabar-dikti.

Hung, H. (2015). Flipping The Classroom for English language Learners to Foster Active Learning. Computer Assisted Language Learning, 28(1). Diakses pada Tanggal 20 Jaunari 2021, Dari https://www.tandfonline.com/doi/abs.

Kim, M., Kim, S., Khera, O., \& Getman, J. (2014). The Experience of Three Flipped Classrooms In An Urban University: An Exploration of Design Principles. The Internet and Higher Education, 22. Doi: 10.1016/j.iheduc.2014.04.00.

Mudlofar, Ali. (2017). Aplikasi Pengembangan Kurikulum Satuan Tingkat Guruan dan Bahan Ajar dalam Guruan Islam. Jakarta: Rajawali Pers.

Sitohang, Risma. (2014). Mengembangkan Bahan Ajar Dalam Pembelajaran Ilmu Pengetahuan Sosial (IPS) SD. Jurnal Kewarganegaraan, Volume 23, Nomor 02, Nopember 2014.

Schwab, K. (2017). The Fourth Industrial Revolution. Crown Business Press.

Shi, Y., Ma, Y., MacLeod, J., \& Yang, H. H. (2020). College Students' Cognitive Learning Outcomes in flipped Classroom Instruction: A meta-analysis of the Empirical Literature. Journal of Computers in Education, 7(1).

Susilawai, Evi. \& Khaira, Imamul. 2020. Analisis Kemampuan Kerjasama Mahamahasiswa Secara Online Dengan Menggunakan Strategi Pembelajaran Online. Temu Ilmiah Nasional Guru (TING) XII. Fakultas Kegurauan dan Ilmu Dosenan Universitas Terbuka.

Susilawati, Evi. (2020). Aplikasi Tutorial Berbantuan Web Untuk Meningkatkan Hasil Belajar Matakuliah Pembelajaran PKn di SD Di Tengah Pandemi Covid-19. E Prosiding Seminar Nasional Virtual Dosenan Kewarganegaraan 2020. Diakses pada Tanggal 25 Pebruari 2021. Dari 
https://ppkn.fkip.uns.ac.id/prosiding-

seminar-virtual-nasional-ppkn-2020.

Susilawati, Evi. (2020). Upaya Meningkatkan

Kemampuan Mahamahasiswa Dalam

Menganalisis Video Pembelajaran Melalui

Strategi Pembelajaran Webinar. Diakses pada Tanggal 20 Pebruari 2021. Jurnal Teknologi Dosenan Vol 3, NO 2, 2020 Dari https://jurnal.unimed.ac.id/index.php.

Thongkoo, K., Panjaburee, P., \& Daungcharone, K. (2019). Integrating Inquiry Learning and Knowledge Management Into a Fipped Classroom to Improve Students' Web Programming Performance in Higher Education. Knowledge Management \& ELearning, 11(3). Diakses pada Tanggal 12 Januari 2021 Dari https://www.kmeljournal.org/ojs/index.php/online.

Turan, Z., \& Akdag-Cimen, B. (2020). Flipped Classroom in English Language Teaching: A Systematic Review. Computer Assisted Language Learning, 33(5-6. Diakses pada Tanggal 18 Januari 2021 Dari: https://doi.org/10.1080/09588.

Yousef, Ahmed Mohamed Fahmy. \& Chatti, Mohamed Amine. (2014). The State of Video-Based Learning: A Review and Future Perspectives. International Journal on Advances in Life Sciences. Vol 6, No 3 \& 4, Tahun 2014. Diakses pada tanggal 6 Januari 2021 dari http://www.iariajournals.org/life sciences 